\title{
Резонансы Ми и коллективные явления в спектрах фотолюминесценции одиночных резонаторов и их цепочек, сформированных на кремниевых структурах с наноостровками $\mathrm{Ge}(\mathrm{Si})$
}

\author{
М.В. Степихова ${ }^{1}$, К.В. Барышникова ${ }^{2}$, М.И. Петров ${ }^{2}$, V. Rutskaia ${ }^{3}$, А.В. Перетокин ${ }^{1}$, А.Н. Яблонский ${ }^{1}$, \\ А.В. Новиков ${ }^{1}$, J. Schilling ${ }^{3}$, 3.Ф. Красильник ${ }^{1}$ \\ ${ }^{1}$ Институт физики микроструктур РАН, д. Афонино, Кстовский р-он, Нижегородская обл.. Россия \\ 603087, у. Академическая, д. 7 \\ ${ }^{2}$ Университет ИТМО, Санкт-Петербург, Россия 199034, Биржевая линия В.О., д. 14 \\ ${ }^{3}$ Martin-Luther-University Halle-Wittenberg, Halle (Saale), Germany 06120, Karl-Freiherr-von-Fritsch- \\ Str., 3 \\ тел:+7 (831) 417-9482, факс:+7 (831) 417-9464, эл.nочта: mst@ipm.sci-nnov.ru
}

DOI 10.34077/RCSP2021-79

В работе обсуждаются резонансные явления, наблюдаемые в спектрах фотолюминесценции (ФЛ) одиночных Ми резонаторов и их цепочек, сформированных на кремниевых структурах с наноостровками $\mathrm{Ge}(\mathrm{Si})$. Интерес к таким структурам обусловлен, прежде всего, возможностями создания на их основе эффективных источников излучения, совместимых с технологией СБИС. Идея развития низкоразмерных резонаторов, в данном случае, связана с перспективами управления процессами взаимодействия излучения с активной средой и, как следствие, оптическими и излучательными свойствами кремниевых материалов.

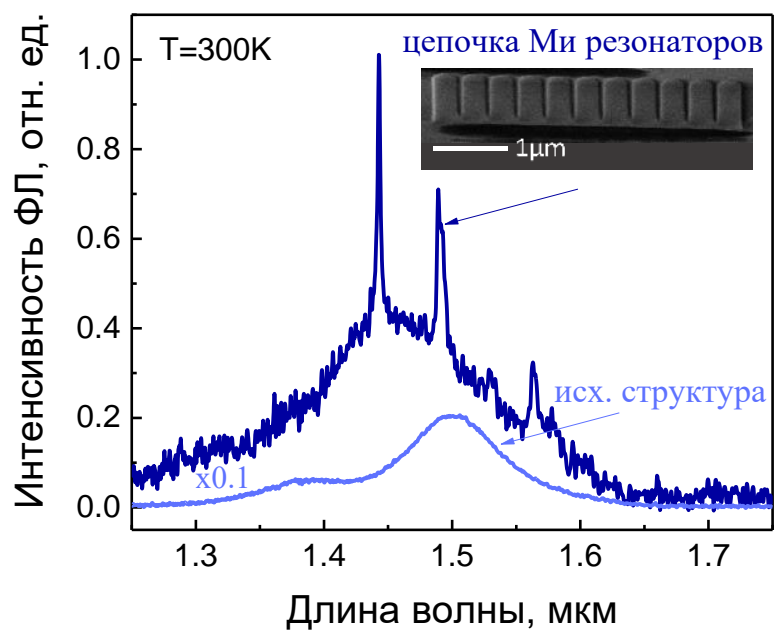

Рис. 1. Спектры фотолюминесценции цепочки Ми резонаторов и исходной структуры с наноостровками $\mathrm{Ge}(\mathrm{Si})$. На рисунке приведен спектр цепочки, представленной 11-ю резонаторами с диаметром 380 нм, расстояние между резонаторами - 50 нм. СЭМ снимок такой цепочки показан на вставке.
Рассмотрены одиночные Ми резонаторы с диаметрами 340 - 500 нм, и их цепочки с числом резонаторов в цепочке, варьируемым от 2 до 11 . Исследуемые резонаторы формировались на кремниевой структуре с 10-ю вертикально упорядоченными слоями наноостровков $\mathrm{Ge}(\mathrm{Si})$, выращенной на подложке SOI. Для формирования резонаторов использовались технологии электронно-лучевой литографии и реактивного ионного травления в индуктивно-связанной плазме. Излучающие свойства полученных резонаторов исследовались методом микро-ФЛ с высоким пространственным и спектральным разрешением. В рамках проведенных исследований выявлены особенности люминесцентных откликов одиночных резонаторов и их взаимосвязь с параметрами резонатора. В спектрах ФЛ цепочек резонаторов обнаружены проявления коллективных резонансов, связываемых с тонкой структурой линий, положение которых непосредственно зависит от диаметра резонаторов, а добротность от их числа. В исследованных цепочках резонаторов добротность линий ФЛ возрастала пропорционально $\mathrm{N}^{3}$, где $\mathrm{N}$ - число резонаторов в цепочке, и достигала значений $\mathrm{Q} \sim 2 \cdot 10^{3}$. Интересно, что коллективные явления наблюдались лишь в цепочках резонаторов с диаметрами менее 460 нм, т.е. резонаторов, вклад в люминесцентный отклик которых вносят основные моды. Другим проявлением коллективных резонансов является значительный рост сигнала ФЛ, который на выделенной длине волны резонанса оказывался сравнимым и даже превышал сигнал ФЛ, измеряемый в исходной, непроцессированной области образца (Рис.1). Последнее объясняется эффектом Парселла. Как показывают результаты теоретических расчетов, фактор Парселла в таких структурах может превышать порядок величины.

Работа поддержана РФФИ (проект 20-52-12062 ННИО_а). 